\title{
Shouldering the past: Photography, archaeology, and collective effort at the tomb of Tutankhamun
}

\author{
Christina Riggs
}

University of East Anglia, Norwich, UK

Corresponding author: Christina Riggs, Art History and World Art Studies, Sainsbury Centre 0.28, University of East Anglia, Norwich NR4 7TJ, UK. Email: c.riggs@uea.ac.uk

\section{Abstract}

Photographing archaeological labor was routine on Egyptian and other Middle Eastern sites during the colonial period and interwar years. Yet why and how such photographs were taken is rarely discussed in literature concerned with the history of archaeology, which tends to take photography as given if it considers it at all. This paper uses photographs from the first two seasons of work at the tomb of Tutankhamun (1922-4) to show that photography contributed to discursive strategies that positioned archaeology as a scientific practice - both in the public presentation of well-known sites and in the self-presentation of archaeologists to themselves and each other. Since the subjects of such photographs are often indigenous laborers working together or with foreign excavators, I argue that the representation of fieldwork through photography allows us to theorize colonial archaeology as a collective activity, albeit one inherently based on asymmetrical power relationships. Through photographs, we can access the affective and embodied experiences that collective effort in a colonial context involved, bringing into question standard narratives of the history and epistemology of archaeology.

\section{Keywords}

Archaeological labour, Egyptian archaeology, history of archaeology, history of photography, Tutankhamun 
The tomb of Tutankhamun is an archaeological discovery more commonly associated with the glint of gold than the gleam of perspiration. But like all archaeological work in Egypt, it took place in conditions involving heat, dust, and bodily strain, to which public and political attention added considerable pressure. Archaeology was in every sense a contact zone, through which colonialism crept into discursive spaces as well as physical ones: the sites, storage magazines, and dig houses that defined 'the field', and the transport links, hotels, equipment suppliers, government offices, lecture rooms, and museums that mediated between field and metropole. This paper revisits that contact zone through the medium of photographs taken during the 1920s excavation of the tomb of Tutankhamun, to consider two interrelated questions: how photography represented the working processes of archaeology, and how photography itself formed part of the collective effort of archaeology. Without the evidential value of photographs, much of the labor that went into colonial-era archaeology would remain unknown, in particular the roles played by indigenous workmen. ${ }^{1}$ It is the affective value of photographs, however, that is just as significant for the historiography of archaeology, because photographs make visible an embodied experience of labor that sometimes distinguishes foreign archaeologists from indigenous workers - but that also brings them into intimate proximity, bodies and brains bumping into each other amid the demands of fieldwork.

The work of excavation was physically and mentally demanding, often taking place under tight constraints of time and money and in a confined, uncomfortable working environment. Even the most strenuous or repetitive physical labor, such as earth removal and heavy lifting, went hand-in-hand with careful scrutiny, always mindful of a potential new discovery or the condition of artifacts and features. Moreover, much of the labor of archaeology required manual and intellectual dexterity, as objects emerged from the ground or the tomb, were cleaned, photographed, drawn,

\footnotetext{
Notes

${ }^{1}$ See Nick Shepherd, "'When the Hand that Holds the Trowel is Black...': Disciplinary Practices of Selfrepresentation and the Issue of 'Native' Labour in Archaeology," Journal of Social Archaeology 3 (2003): $334-52$.
} 
and recorded, then carried, sorted, stabilized, and packed. All these activities required many more human (and non-human) actors than the heroic white man popularly credited with archaeological discovery, yet most historical accounts of archaeology in Egypt perpetuate a narrative that resembles - not coincidentally - late Victorian adventure tales in the manner of $\mathrm{H}$. Rider Haggard or G. A. Henty. ${ }^{2}$ The hero may be flawed, but he perseveres against the odds, his 'native' workmen in his shadow and at his command.

The most famous find of twentieth-century Egyptian archaeology seemed readymade for such a narrative: lead excavator Howard Carter had spent much of his career in the archaeological wilderness thanks to an uncompromising temperament, and his patron George Herbert, fifth Earl of Carnarvon, was an aristocratic playboy turned Egyptological dilettante who held the permit to excavate in the Valley of the Kings, behind the western cliffs opposite the Nile at Luxor - an area many Egyptologists did not think worth the effort of exploring further. From 1917, Carter and his chief foreman, Ahmed Gerigar, directed gangs of up to 100 men and boys (some girls, too) in a clearance operation, shifting tons of sand and rubble to the level of the valley floor. After the men uncovered the flight of steps and subterranean sealed doorway of what proved to be Tutankhamun's tomb, in November 1922, Carter recognized the need for assistance beyond his solo capabilities and more specialist than what his Egyptian workmen offered. He quickly assembled a team - as the press would term it comprising experts from the prestigious Metropolitan Museum of Art, whose Egyptian expedition was based near the valley, as well as a British chemist long employed by the colonial government in Egypt. The identities and careers of most of these men are well documented, in particular photographer Harry Burton and archaeologist Arthur C. Mace

\footnotetext{
${ }^{2}$ Conventional and empirically driven accounts abound, such as Jason Thompson, Wonderful Things: A History of Egyptology, 1: From Antiquity to 1881 (Cairo and New York: The American University in Cairo Press, 2015). For Henty and Haggard, see: Wilson Chacko Jacob, Working out Egypt: Effendi Masculinity and Subject Formation in Colonial Modernity, 1870-1940 (Durham, NC and London, 2011), pp.32-41; Roger Luckhurst, The Mummy's Curse: The True History of a Dark Fantasy (Oxford: Oxford University Press, 2012), pp.185-207.
} 
(both British, but employed by the Egyptian Expedition), and the chemist Alfred Lucas. ${ }^{3}$ Carter assiduously acknowledged their contributions, which were paid for by the museum and the Egyptian government respectively. Only Carter's own salary, and that of his friend Arthur Callender, a retired Egyptian railways engineer, were paid by Carnarvon, along with the other excavation costs. These financial arrangements, and distinctions of who worked for whom, mattered a great deal to those involved, despite the unified face that the terminology of teamwork implied.

In the first two books published about the tomb of Tutankhamun, Carter also acknowledged his four Egyptian ru'asă', or foremen (as it is conventionally translated; the singular is ra'īs), whose names he stated in the prefaces: chief foreman Gerigar, and foremen Hussein Ahmed Said, Gad Hussein, and Hussein Abu Awad. ${ }^{4}$ Nowhere else in the excavation records, photographs, or in press coverage are these men identified by name, nor their pay arrangements, working schedules, or responsibilities disclosed. Carter's diaries and journals record payments for the salaries and household accounts of his Egyptian domestic staff (whom he referred to collectively as 'servants' and individually by name and/or specific role), but the diaries and journals make only passing references to any of the Egyptian excavation staff, such as "Paid men for the week," or "Paid men \& Reises." ${ }^{5}$ Other than these cursory entries, no Egyptian field workers on the ten-year-long Tutankhamun excavation appear in the archive that Carter

\footnotetext{
${ }^{3}$ Burton: Ronald T. Ridley, "The Dean of Archaeological Photographers: Harry Burton," Journal of Egyptian Archaeology 99 (2013): 117-30. Mace: Christopher C. Lee, ...The Grand Piano Came by Camel: Arthur C. Mace, the Neglected Egyptologist (Edinburgh and London: Mainstream Publishing, 1992). Lucas: Mark Gilberg, "Alfred Lucas: Egypt's Sherlock Holmes," Journal of the American Institute for Conservation 36 (1997): 31-48.

${ }^{4}$ Howard Carter and A. C. Mace, The Tomb of Tut.ankh.Amen, Volume I (London, 1923 [2003]), p.xv [xxvii]; Howard Carter, The Tomb of Tut.ankh.Amen, Volume II (London, 1927 [2001]), p.xxiv. For the excavation of the tomb, and its immediate impact, see Christopher Frayling, The Face of Tutankhamun (London and Boston: Faber and Faber, 1992); Paul Collins and Liam McNamara, Discovering Tutankhamun (Oxford: Ashmolean Museum, University of Oxford, 2014). For a critical consideration of the excavation in light of contemporary Egyptian politics, see Elliott Colla, Conflicted Antiquities: Egyptology, Egyptomania, Egyptian Modernity (Durham, NC: Duke University Press, 2007), pp.172-210. ${ }^{5}$ Carter's journals and diaries have been scanned and transcribed by the Griffith Institute, Oxford University: <www.griffith.ox.ac.uk/discoveringTut/journals-and-diaries/>. The quoted references occur in the journals for the fourth and fifth season, 26 October entries in both cases. For salaries and accounts concerning the domestic staff, see in particular the diaries of the first (e.g. 1 June entry) and second seasons (e.g. 1 March, 18 March entries).
} 
himself maintained; if Carter (or Gerigar, feasibly) used separate registers or account books to record this information, they have not survived. In the minds of Carter, his immediate colleagues, and the media and public too, the 'team' seems not to have included Egyptians in any capacity.

Photographs of the excavation show a different story, however. A sizable Egyptian workforce was essential to the project, from the carpenters who made scores of trays and crates for the artifacts, to the basket boys who carried rubble to backfill the tomb entrance, to the experienced men - in all likelihood, the ru'as $\bar{a}^{\prime}-$ who were involved in the delicate task of disassembling the gilded wooden shrines that filled the burial chamber. Because of the tremendous publicity the tomb generated, a greater number and diversity of photographs were taken of work in progress on the site than would have been done for a more conventional excavation. During the first two field seasons in particular (December 1922 to May 1923; October 1923 to February 1924), the cameras of tourists and journalists surveilled the site intently; so, too, did the cameras of fellow archaeologists and team members. In those first two seasons, a contract between Carnarvon and London's The Times gave that newspaper and its sister-publication, The Illustrated London News, privileged access to photographs taken in the tomb by Burton, as well as other photographs, for instance some taken by Carnarvon himself. As a result, photographs documenting work in progress at the tomb of Tutankhamun can be divided for our purposes here into two broadly defined groups: first, copious photographs taken outside and in the vicinity of the tomb, many of which became property (at least in print form) of The Times, and second, the Burton photographs, whose negatives and prints became part of the excavation archive compiled by Carter - and divided by him between his personal files and albums, now in the Griffith Institute, Oxford University, and Burton's employer, the Metropolitan Museum. ${ }^{6}$ Taken together with other glimpses - and gaps - in contemporary media

\footnotetext{
${ }^{6}$ Given that multiplicity and reproducibility are inherent to the photographic medium, there is considerable overlap between The Times' material and the excavation archive, especially when one attempts to trace original negatives, copy negatives, and printed images: see Christina Riggs, "Photography and Antiquity in the Archive, or How Howard Carter Moved the Road to the Valley of the Kings," History of Photography,
} 
coverage and in the excavation archives, these photographs allow us to explore the range of labor that went into the production of knowledge about this fabled discovery.

This paper argues that the representation of fieldwork through photography makes a strong case for theorizing colonial archaeology as a collective activity undertaken by foreign and indigenous actors, even as the photographs themselves speak to asymmetrical power relationships, age-old tropes of the Orientalized Other, and the complexities of identity and subjectivity in Egypt's emergent, notionally independent nation-state. Photography itself thus invites us to question the history and epistemology of archaeology, not only to produce a counternarrative to conventional hero-discoverer accounts, but also - and arguably more significantly - to recover and foreground the affective experiences of labor in a colonial context. After considering the affective qualities of photographs and photographic images in archaeology, I turn to the two groups of Tutankhamun photographs described above to look first at how photography represented the work of archaeology in contemporary press accounts, and then at how 'official' photographer Harry Burton depicted work inside the tomb. Burton's own methods confirm the complexities of working relationships in colonial archaeology, exemplifying the asymmetries of representation and communication through which the now-familiar tropes of Tutankhamun took shape: the boy-king, his wonderful things, and the secrets the tomb still promises to reveal, if heroarchaeologists succeed. ${ }^{7}$

\section{Archaeological affect}

As both a practical technique and a representational practice, photography attests the collective nature of archaeological effort in colonial Egypt, wider recognition of which would foster a radical rethink of Egyptian archaeology's disciplinary pasts and futures -

40 (2016): 267-82. The Oxford and Metropolitan Museum archives also are not identical, despite efforts since the 1950 s to reconcile and equate the two.

7 "What Lies Beneath? A Tantalizing Clue to the Location of a Long-sought Pharaonic Tomb," The Economist, 8 August 2015 (print edition; accessed online, <www.economist.com/news/books-andarts/21660503-tantalising-clue-location-long-sought-pharaonic-tomb-what-lies-beneath>). 
and of the untapped potential of photography for writing histories of archaeology. ${ }^{8}$ To realize this potential fully, however, studies of archaeological photographs must take in both the evidential and affective values of the images. Photographs are more than what they represent, and photography is more than a recording device, as a well-developed body of literature in visual and historical anthropology has demonstrated. ${ }^{9}$ Trained to treat photographs as records of fact (the photograph is what the photograph shows), archaeologists have tended to be less critical of their representational and archival practices than anthropology, whose postcolonial turn in the 1970s and 1980s can be attributed in part to its self-conception as a study of people, rather than the 'things' that have been archaeology's avowed concern. Regardless, photography was central to the working methods and epistemic priorities of both disciplines as they developed in the colonial and imperial climes of the late nineteenth and early twentieth centuries.

Elizabeth Edwards has recently argued that the affective qualities of photographs, which have heretofore been configured as a polarity to photography's evidential, knowledge-producing character, should instead be repositioned in tandem with the evidence base that photographs created and the meanings they accrued. ${ }^{10}$ "Photography has always been a social act," she notes, "bounded to a greater or lesser extent by power relations," especially in colonial contexts. Taking photographs, being photographed, looking at, sharing, exchanging, and copying photographs were such common activities in the field (whether on site, in the dig house, or traveling to and from them) that they will have been routine, as were the differences in status and

\footnotetext{
${ }^{8}$ See also Sudeshna Guha, "Visual Histories, Photography and Archaeological Knowledge," Lalit Kala Contemporary 52 (2012): 29-40; Sudeshna Guha, "Introduction: Archaeology, Photography, Histories," in Sudeshna Guha (ed.) The Marshall Albums: Photography and Archaeology (Ahmedabad, 2010), pp.11-67; Jennifer A. Baird, "Photographing Dura-Europos, 1928-1937: An Archaeology of the Archive," American Journal of Archaeology 115 (2011): 427-46; Frederick N. Bohrer, Photography and Archaeology (London: Reaktion Books, 2011); Philip Carabott, Yannis Hamilakis and Eleni Papargyriou, "Capturing the Eternal Light: Photography and Greece, Photograpy of Greece," in Philip Carabott, Yannis Hamilakis and Eleni Papargyriou (eds.) Camera Graeca: Photographs, Narratives, Materialities (Farnham, 2015), pp.3-21. ${ }^{9}$ Elizabeth Edwards, Raw Histories: Photography, Anthropology, and Museums (Oxford: Berg, 2001); Elizabeth Edwards and Janice Hart (eds.), Photographs, Objects, Histories: On the Materiality of Images (London and New York: Routledge, 2004); Christopher Pinney, The Coming of Photography in India (London: British Library, 2008).

${ }^{10}$ Elizabeth Edwards, "Anthropology and Photography: A Long History of Knowledge and Affect," Photographies 8 (2015): 235-52.
} 
power between and among the foreign archaeologists and their indigenous employees. For anthropology, Edwards uses 'affect' to encompass the subjective, embodied, and emotional experiences of all parties in the fieldwork encounter, to which we can also add subsequent viewers and users of the photographs. For archaeological photography in a colonial or semicolonial context - and Egypt in 1922 was arguably somewhere between the two - what photographic images represent is often a form of presence glossed over, forgotten, or suppressed in written modes of discourse.

Photographs also give us glimpses of personal interactions, physical contacts, and haptic details that could not or would not be attested in any other medium: the grip of hands on tools or equipment; the texture of clothing, scuffed shoes, or (for the Egyptian workers) bare feet; the pressure of bodies pressing against each other; and, indeed, the gleam of perspiration on skin or sticking under the arms of a sweat-stained shirt. Photography does not illustrate the history of archaeology: it is the history of archaeology and its historiography as well, for as objects and as images, photographs of work in the field continue to exert an affective response, as anyone who has worked with them soon discovers, especially in the heightened atmosphere of an archive. ${ }^{11}$ Dust-covered children carrying baskets of rubble, Egyptian workmen gripping metal rails under a blazing sun, Howard Carter in tweeds and a bowtie that almost make us itch: for many reasons, photographs of archaeology often make for uncomfortable viewing, but they are all the more illuminating for that.

\section{The press gang}

Historians of science are accustomed to thinking about knowledge production as a collective effort, but with a few notable exceptions, histories of archaeology often stop short of incorporating 'native' labor fully within the collective. Either they overlook indigenous contributions altogether, which is typical in conventional accounts, or they

\footnotetext{
${ }^{11}$ For the distinctive viewing conditions an archive can foster, see Gillian Rose, "Practising Photography: An Archive, a Study, some Photographs and a Researcher," Journal of Historical Geography 26 (2000): 555-71; Liam Buckley, "Objects of Love and Decay: Colonial Photographs in a Postcolonial Archive," Cultural Anthropology 20 (2005): 249-70.
} 
are stymied by archival absence. Even where indigenous workers have archival presence, for instance in archaeological photographs, it may be frustratingly impossible to identify represented individuals by name. ${ }^{12}$ The terminology deployed in archaeology, then and now, confounds us as well: we use 'archaeologist' to refer only to the white men, and a very few women, who ran things in the field and put their names on the title pages of books. ${ }^{13}$ Indigenous workers, no matter how experienced and skilled, were not archaeologists: they were diggers, gangs, men, or (regardless of age) boys, if they were mentioned at all. These differential terminologies, and the use of collective nouns like "team" or "gang," tend to efface all individual contributions to the work of the group. The effect appears especially invidious where the work of subalterns, who almost always outnumber foreign specialists, is at stake, yet asymmetry, inequality, and anonymity were inherent to collective effort, as Bruno Latour has cautioned: “By collective, we don't mean an action carried over by homogeneous social forces, but, on the contrary, an action that collects different types of forces woven together because they are different." 14

Asymmetries, inequalities, and anonymity suffuse photographs of labor at the tomb of Tutankhamun, not only between foreign and indigenous staff members, but between the British or Egyptian participants themselves; social relations were not binary, but multifaceted. Some of the individuals involved in the Tutankhamun excavation had known each other and worked together for decades, however different their individual experiences were or how difficult the interpersonal relationships enabled (or disabled) by the colonial encounter. Being 'in the field' was an embodied reality, not an abstraction: these men - and some boys - brushed against each other's

\footnotetext{
${ }^{12}$ On the anonymity of indigenous laborers in archeological photographs, see Nick Shepherd; J. A. Baird. <add page refs> Some archeological archives do preserve detailed staff registers, even identifying staff in photographs: Stephen Quirke, Hidden Hands: Egyptian Workforces in Petrie Excavation Archives, 1880 1924 (London, 2010), <add page refs>.

${ }^{13}$ A related observation can be made for the wives (and other family members) of white, male archeologists, many of whom contributed actively to work such as drawing, cleaning, and cataloging objects, or cataloging photographic negatives, without being paid or credited as 'team' members.

${ }^{14}$ Bruno Latour, Reassembling the Social: An Introduction to Actor-Network-Theory (Oxford: Oxford University Press, 2007), pp.74-5.
} 
clothing and bodies, smelled each other's sweat, waited, conferred, adjusted, maneuvered, and balanced, day in and day out for months and years. The split seconds caught by a camera may be flattened to shades of gray in the photographic image, but there is a depth and fine-grained texture to the encounters these photographs represent, well beyond the printed surface. Photographs of work taking place outside the tomb of Tutankhamun are abundant in two senses, first in terms of the numbers that were taken (and by multiple photographers), and secondly, for the "plentifulness, plenitude and potential" it implies in the medium itself. ${ }^{15}$ Photographs record unexpected details and random information, an 'excess' that frustrated earlier photographers but offers a boon to researchers now.

From the moment of its discovery, news of this apparently untouched royal tomb, belonging to an ancient Egyptian ruler hardly anyone had heard of, made headlines around the world. But it was only two months later, in late January 1923, that press coverage intensified, at the point that objects began to be removed from the first of what would prove to be four chambers. The timing of these activities was one factor in the delay between discovery and the surge of press interest. It had taken Carter several weeks to make practical arrangements such as security, staffing, equipment, and nearby storage and workspace. Another important factor was the availability of photography for the illustrated press, which is my first point of departure. At Christmas 1922, Carnarvon had signed a contract with London's The Times, giving the paper exclusive rights to 'official' photographs from the tomb and reports of the work, in exchange for a $£ 7,500$ fee and a percentage of the proceeds from selling on the image rights. ${ }^{16}$ Inside the tomb, Carter arranged for Burton, staff photographer to the Metropolitan Museum of Art's neighboring excavations (and a trusted acquaintance of long standing), to photograph objects in situ, and again once they had undergone conservation in a nearby tomb repurposed as 'the laboratory'. The area immediately

\footnotetext{
${ }^{15}$ Edwards, "Anthropology and Photography" (note 10).

${ }^{16}$ For details of The Times' contract, see Howard Carter and Nicholas Reeves, Tut-ankh-amen: The Politics of Discovery (London: Libri, 1998); T. G. H. James, Howard Carter: The Path to Tutankhamun (London and New York, 2001 [1992]), <add page citations>.
} 
outside the tomb of Tutankhamun was a photographic free-for-all, however; the cameras of tourists and other news outlets were ever-present, putting many photographs beyond the control of Carter, Carnarvon, or The Times. As an established winter resort, the town of Luxor on the opposite side of the Nile was well equipped with photographic suppliers, where negatives could be printed on photo paper or postcards. As The Times' sister paper, the weekly The Illustrated London News, observed in a February 1923 edition, work on site was accompanied by the "click of the ubiquitous Kodak," which the paper juxtaposed with the "constant creaking of the crude waterwheels which abound in the locality," contrasting the modern Western technology of photography with an ageless Oriental primitivism. ${ }^{17}$

Photographs of the objects being brought out of the tomb focus (or at least purport to focus) on archaeological objects. But human activity, whether by the Egyptian workers or the 'team', was crucial for the visual interest of reportage from the site. Harry Burton would eventually take almost 3,000 photographs of the tomb interior and the objects discovered, scores of which The Times and its affiliates published throughout the decade-long project. However, the excavation site and its heroic archaeologists had an instant and topical appeal, as did the high-profile visitors, both foreign and Egyptian, who came to witness the action. In the first months, and when the burial chamber was opened in the following season, work-in-progress shots helped transport readers to the Valley of the Kings by proxy, in the way that mass communication uniquely enables.

One such photograph, taken for The Times but never published, has a familiar feel from other photographs and graphic illustrations of physical labor in a colonial context (Figure 1). Carter, wearing a pith helmet and his usual natty tweeds, stands at the top of the tomb stairs observing two turbaned Egyptian men as they maneuver one of the large wooden trays used to ferry objects from the tomb to the 'lab'. At the top right of the picture, a third Egyptian figure also stands by, cropped to chest-height by the

\footnotetext{
17 "The Suggested Pharaoh of the Exodus Causes an Influx into Egypt: Tutankhamen Attracts Tourists," Illustrated London News, 10 February 1923, 196-7.
} 
camera, while at the bottom right, a woman in European dress - possibly Carnarvon's daughter - relaxes in one of three wicker armchairs, in shade that makes her folded parasol unnecessary for the moment. Captured from above, this frozen moment suggests the British archaeologist supervising while subalterns did the dirty work of archaeology. But there is more than that in this one photo: Carter and the cropped Egyptian worker at the top right mirror each other's stance, which is expectant and alert as if both are at the ready to assist with the laden tray if necessary. The two men carrying the tray have adjusted their bodies to keep it level as they crest the stairs, one with his arms overhead, the other bending forward so that the fragile bouquet inside (number 18, its inventory card tells us) will not fragment even further. The pith helmet, parasol, wicker chairs, and fly whisk and carafe at the left of the image, are part of the material culture of colonial life - and leisure - in hot climates, but there is a sense, too, that all five people share a focus on object 18 , as does the photographer who centered it in the picture.

[Insert Figure 1 near here.]

Although taken under similar circumstances to those in Figure 1, the photograph reproduced here as Figure 2 differs in its vantage point - it was taken by an unknown photographer near the tomb entrance, not from above - and in the way it depicts close coordination and physical contact between the British and Egyptian workforce. ${ }^{18}$ Divested of his usual waistcoat, Carter and the same Egyptian man seen bending forward in the previous photograph struggle together at the top of the stairs with the side of a gilded, hippo-headed wooden couch. The effort of the work is obvious: a ticking-covered pillow cushions the weight of the couch on Carter's shoulder, and the Egyptian man - likely one of the foremen, judging by his frequent appearance in these photos - helps lift Carter's flagging arm. Their intimate contact, hand to arm, knees almost touching, did not preclude publication of this photograph, whose close-up view

\footnotetext{
18 The close vantage point at which the photograph was taken suggests that the photographer was a British or American staff member, possibly Lindsay Hall of the Metropolitan Museum of Art's Egyptian Expedition. I have not been able to confirm this suggestion, however, or to locate a negative of the photograph.
} 
lent it an immediacy lacking in the photographs taken from ground level. That the Egyptian man adopts, literally, a supporting role to Carter may have matched expectations, and in any case, it is Carter's face, left hand, and the carved front of the ancient couch that are in sharpest focus. When The Illustrated London News published this photograph in a double-page spread on 17 February 1923, its caption simply identified 'Mr Carter and an Egyptian' as the men at work, acknowledging the presence of the second human being while declining to name him.

[Insert Figure 2 near here.]

A few months later, Carter and Arthur Mace (like Burton, seconded from the Metropolitan Museum excavations) used the same photograph in the book they rushed to print about the tomb, this time without either naming the Egyptian man or referring to his presence. ${ }^{19}$ Both Carter and Mace will have known this man well and worked alongside him on an almost daily basis for months. They certainly knew his name, but they must have assumed either that their readers were disinterested in such a detail, or that it was inappropriate to the task of archaeological record-keeping and publication. There is, as Nick Shepherd has observed,

a consummate irony here, that archaeology, a discipline whose methodologies involve maximum physical exertion, hours spent in the pit or at the sieve, so routinely should lose sight of its own conditions of production. Like the clue in a murder-mystery, that which is nearest at hand is least remarked. ${ }^{20}$

The elision or erasure of indigenous workers, at the point when archaeology was at its most archaeological - moving earth and revealing objects in an antique land takes place in plain sight, thanks to the camera's (or cameras') presence and the ability of photographs, long after the fact, to reveal what otherwise went unnoticed or unremarked. Ostensibly, The Times' photographs met public demand for news of the tomb, while for tourists, official visitors, or the team members themselves, taking photographs from unrestricted vantage points outside the tomb demonstrated 'I was

19 Carter and Mace, The Tomb of Tut.ankh.Amen, p.xxxii (note 4).

${ }^{20}$ Nick Shepherd, <add page ref> 
there'. Yet a closer look at how The Times and The Illustrated London News presented the photographs and described work at the tomb invites us to think about the values photography helped create and enshrine where the work and, crucially, the results of archaeological effort were at stake.

\section{Men at work}

The image of Carter shouldering the hippo couch with (if my surmise is correct) a ra'īs was one of seven photographs reproduced across two pages in The Illustrated London News. The popular paper had featured the tomb of Tutankhamun in almost every weekly edition since early January 1923. For the 17 February spread, the headline “Preserving and removing: The delicate task of taking Tutankhamen's furniture from his tomb" concisely summarized the images of packing cases, a chariot lashed to a carrying tray, and the so-called laboratory set up in the nearby tomb of King Seti II, with cluttered trestle tables and Thonet bentwood chairs pressed tight against the ancient relief-covered walls (Figure 3). ${ }^{21}$ In separate photographs, near-mirrors of each other across the paper's gutter, Mace and chemist Alfred Lucas appear in the laboratory, each engaged in delicate work on an object from the tomb, their faces in profile and their heads angled forward to concentrate on their tasks and tools (a brush for Lucas, seen here in Figure 4, and fine bellows for Mace). Beneath all seven photographs (a general view of the valley showing the position of both tombs, the laboratory tomb interior, two images of transport and packing, and the three photos of Lucas, Mace, and Carter and the $\left.r a^{\prime} \bar{i} s\right)$, text at the bottom of the spread thematically links them in a tone meant to instruct as well as inform the reader/viewer:

The work of furniture removal, as understood by archaeologists, is one requiring the utmost care and delicacy, aided by all the resources of science for the chemical preservation of fragile objects liable to crumble at a touch when exposed to the air after 3000 years.

Rather than a mundane task of moving house, 'furniture removal' here becomes

\footnotetext{
21 "Preserving and Removing: The Delicate Task of Taking Tutankhamen's Furniture from his Tomb," The Illustrated London News, 17 February 1923, 238-9.
} 
another archaeological specialty, for which the 'resources of science' and chemical intervention must be marshaled on site.

[Insert Figures 3 and 4 near here.]

This emphasis on the scientific nature of archaeology would run throughout the media coverage of the excavation as well as Carter's own reports. The exactitude of the work required expertise, rigor, and vigilance, all of which made it the sole preserve of the British participants, regardless of their level of education: Mace and Lucas held degrees, but Carter had little formal schooling, having learned archaeology on the spot after first working as an archaeological draftsman. The Egyptian workmen, even the foremen, could not be included in the discourse of science. They stood outside it, not so much for their lack of education, but for their 'Oriental' mindset, a frequent source of comment by excavators of the time. The director of the Metropolitan's Expedition, Herbert E. Winlock, characterized Egyptians and other 'Orientals' as inveterate twisters of facts, while Harvard-funded American archaeologist George A. Reisner was one of many Egyptologists of the time who scorned Egyptians ("a half-savage race") as incapable of self-rule. ${ }^{22}$ For that matter, Reisner also heaped scorn on Carter, whom he deemed an inadequate archaeologist with questionable links to the antiquities trade. Thus did Western archaeologists mark scholarly boundaries between themselves, as well as between themselves and their Egyptian co-workers.

Every scientist needed a laboratory, and the above-ground chambers of KV15 provided the space needed to repair, record, photograph, and store the objects brought out of the tomb, which were packed and sent to the antiquities museum in Cairo at the end of each season. The text accompanying The Illustrated London News spread pointed readers to the lab's trestle tables laden with "bottles, wadding, and implements used in

\footnotetext{
${ }^{22}$ Winlock, in Donald Malcolm Reid, "Nationalizing the Pharaonic Past: Egyptology, Imperialism, and Egyptian Nationalism, 1922-1952," in Israel Gershoni and James Jankowski (eds.) Rethinking Nationalism in the Arab Middle East (New York: Columbia University Press, 1997), pp.127-49, 133-5. Reisner, in James F. Goode, Negotiating for the Past: Archaeology, Nationalism, and Diplomacy in the Middle East, 1919-1941 (Austin: University of Texas Press, 2007), p.88.
} 
the processes of preservation" (see Figure 3). ${ }^{23}$ Regular readers would already have been familiar with the wadding, for the News had highlighted it three weeks earlier with a headline announcing that the archaeologists would use $11 / 2$ miles of this medicalgrade material to wrap and cushion the objects. To The New York Times, the bandaging was reminiscent of recent war casualties, a comparison that implicitly likened the artifacts to wounded soldiers and reinforced the identification of the archaeologists with scientific, even medical, experts. ${ }^{24}$ The comparison is also a salient reminder that to European and American audiences, coverage of the Tutankhamun tomb was a welcome bright spot in the post-war era, and the first positive press to come out of Egypt in some time. Tourism to the country had only just recovered from the disruption of World War I and the country's 1919 uprising against British military occupation. The military remained in place, but in February 1922, Britain broke off negotiations with Egyptian political parties to declare an independent Egyptian state - one in which British 'advisers' occupied every ministry, and Britain retained control of Egyptian foreign affairs and the Suez Canal. ${ }^{25}$

The political situation was crucial to what would transpire over the course of the Tutankhamun excavation, and the first two seasons in particular. Archaeology in Egypt had likewise been disrupted by the war and its aftermath. German excavators lost their site concessions, for instance, which the French-run antiquities service redistributed to British and French archaeologists. The service was headed by Pierre Lacau, who had been unable to take up the post properly until the war ended. In the spirit of the newly independent state, but also from personal conviction, Lacau planned to restrict the liberal division of finds that foreign archaeologists in Egypt were used to receiving; some curtailed their excavations because of this. Carter and Carnarvon, who had held the Valley of the Kings concession since 1914, expected to receive a portion of the

\footnotetext{
23 "Preserving and Removing: The Delicate Task of Taking Tutankhamen's Furniture from his Tomb," The Illustrated London News, 17 February 1923, 238-9.

${ }^{24}$ Frayling, The Face of Tutankhamun, p.21 (note 4).

25 <Refs, e.g. Goode, new book by Reid>

The classic study of the period remains Israel Gershoni and James P. Jankowski. Egypt, Islam, and the Arabs: The Search for Egyptian Nationhood, 1900-1930 (New York and Oxford: Oxford University Press, 1986).
} 
Tutankhamun artifacts under the old division terms. So too did the Metropolitan Museum of Art, hence its initial eagerness to lend staff to the project. ${ }^{26}$ In the increasingly fraught relationship between Carter and antiquities officials, in particular Lacau, one source of tension was Carnarvon's contract with The Times, which had offended the Egyptian press and angered rival British and American papers. But another, though less openly acknowledged, reason for simmering hostilities in the supervision of the dig was the ultimate fate of the objects being so carefully extricated from the tomb and preserved with "all the resources of science."27

With actual and intellectual control of the Tutankhamun artifacts at stake, the emphasis that Carter and the contractually privileged news outlets placed on the 'scientific' nature of the work acquires a particular significance - and the photographs of men at work likewise. The only 'scientists' in the photographs may have been Carter, Mace, Lucas, and so forth, not the Egyptian workmen, but when Carter spoke on behalf of science and against the Egyptian antiquities service, he was not speaking against 'Egyptians' as a homogeneous group. His target was the Egyptian government, which in this case included Europeans like Lacau and regional inspector Reginald Engelbach, who was British. Whatever threat Lacau and his colleagues posed to science is never made explicit. General incompetence is implied, interference is mentioned, but the real concern was over changes to the preindependence status quo of Western-led archaeology in Egypt and, by extension, the prerogative to speak of and for the country's ancient past.

Photographing work on site and in the lab thus went far beyond reportage or proxy tourism. The photographs, as well as the processes of taking, developing, and distributing them, offered authentication of the archaeological work being done and demonstrated its scientific nature. To do this effectively, photographs had to depict the

\footnotetext{
${ }^{26}$ Carter consistently emphasized that objects sent to Cairo were there pro tem, in advance of the division, and after Carnarvon's sudden death in April 1923, he continued to assert Lady Carnarvon's expectation that she would receive a selection of objects. Towards the end of the clearance work in 1929, she accepted instead reimbursement of the excavation costs from the Egyptian government, nearly $£ 36,000$, negotiated by Carter. James, The Path to Tutankhamun, pp 430-4.

27 "Preserving and Removing," pp.238-9 (note 24).
} 
Egyptian workforce, and could depict Egyptians working alongside foreigners. As long as a foreign archaeologist was in charge, indigenous laborers could be seen (if not said) to contribute in some way to the collective effort that was the science of archaeology. Another issue of The Illustrated London News, from 20 January 1923, underscores the complex motivations and ascriptions of meanings involved in such photographs, for beneath the aforementioned headline about miles of wadding, photographs show Mace or Carter "follow[ing] and supervis[ing]" the "Egyptian bearers," as one caption has it. Like Reisner's commanding and patronizing tone toward his own Egyptian staff members, this phrasing reveals an existing attitude, but also imposes a hierarchical stress some of the photographs do not necessarily carry - all the more important, then, for words to reinforce or impose a contrast between the trustworthiness of the experts and the lassitude of the indigenes: on the same page, a photograph of Carter and a topee-clad Callender carrying a tray entirely on their own bears a caption to explain that the tray holds a "casket of jewels too precious to be entrusted to any other hands." 28

Authentication, authority, scientific rigor, and security: photographing the work of archaeology enabled archaeology to do many kinds of work, far beyond its purported remit of discovering, recovering, and preserving the ancient past. Since the first use of daguerreotypy in Egypt in the 1840s, photographs had documented - and created - a Western presence in exotic lands, a presence concomitant with mastery, control, and technical prowess. Even where they show Egyptians and foreigners working closely together, like Carter and the ra'īs in Figure 2, photographs of archaeology thus tap into a seam of enduring visual tropes, which work against reading them as collective effort and instead encourage a reading based solely on inequalities. Those inequalities were real, without a doubt, but so too was an interest (in every sense) in representing archaeology in action. The fame of the Tut discovery - and, until the 1924 'strike', the impact of The Times' contract - meant that both the British and American team members and the

\footnotetext{
28 "Retrieving Tutankhamen's Treasures: '1 1/2 Miles of Wadding," The Illustrated London News, 20 January 1923, 84.
} 
Egyptian workforce were photographed more often, and in a wider array of working contexts, than on most excavations. For instance, Carnarvon himself photographed the carpentry workshop tucked into a bay of cliffs nearby, where local carpenters made the trays, crates, and scaffolding that was essential to the work (Figure 5). The photograph, which appeared in The Times on 9 May 1923, shows the men and boys awkwardly paused in their work, tools held up as signs of 'work' rather than in any functional posture. The carpentry trade was the domain of Coptic Christians in this area, hence the caps the two boys and two tool-wielding men wear; the turban of the man at far left identifies him as Muslim. The Times makes no mention of this detail, but it encourages us to broaden our understanding not only of what kinds of work archaeological labor comprised, but also what kinds of individuals made up the collective whose efforts we are meant to see but not to recognize. However outward-looking photographs like this one may appear to be, given that they were made partly with the press in mind, they were as important for archaeology's self-understanding, which was by definition 'self' not 'other'. Photography and other methods of visualization were what allowed archaeology to represent - and replicate - itself as a discipline and, crucially, a scientific one at that. ${ }^{29}$

[Insert Figure 5 near here.]

\section{In the archive and in the tomb}

As an 'immutable mobile', to use the terminology of actor-network theory, photography was a key act of inscription in archaeological processes. ${ }^{30}$ The camera, the darkroom, photographic supplies, the circulation of negatives, prints, and published reproductions - all were actants in a network, contributing to the collective effort of knowledge production alongside the human actants captured in the photographs themselves. The reasons why archaeological labor was photographed are thus inextricable from how it

\footnotetext{
${ }^{29}$ Sudeshna Guha, "Mortimer Wheeler's Archaeology in South Asia and its Photographic Presentation," South Asian Studies 29 (2003): 43-55.

${ }^{30}$ Bruno Latour, "Visualisation and Cognition: Thinking with Eyes and Hands," in Henrika Kuklick (ed.) Knowledge and Society: Studies in the Sociology of Culture Past and Present (Greenwich, CT: JAI Press, 1986), pp.1-40.
} 
was photographed, as well as how these photographs did, or did not, become incorporated into the excavation archive. In the rest of this paper, I focus on the main archive associated with the tomb of Tutankhamun, which does not include most of the photographs discussed above, thanks in part to their status as property of The Times. Taken together with the material forms of the surviving negatives and prints, this archival history brings a further dimension to the interrelationship of photography, archaeology, and what I have been characterizing as a collective, albeit inequitably credited, effort. As several postcolonial engagements with archives have shown, collections of documents, photographs, and their archival supports reveal processes of inclusion and exclusion, ordering and disordering, that draw into question the assumptions on which disciplinary identities and systems of knowledge have relied. Excavating the archive offers the possibility of disassembling these systems in the hope that other histories and alternative ways of knowing may emerge. ${ }^{31}$

Howard Carter curated his own archive for the Tutankhamun excavation, which passed on his death in 1939 to the Griffith Institute at Oxford University. It was Carter who decided which negatives and print albums stayed in his possession, and which were given to the Metropolitan Museum in New York, since it had lent photographer Harry Burton to the team. Both exclude almost all the photographs used by The Times and The Illustrated London News to show work on site. Since Carter had used images of the hippo couch-carrying in his own book, his access to prints of these photographs, if not their negatives, was not the barrier; the proprietor of the News was an old friend and with Burton - one of the named executors of Carter's estate. Instead, The Times and The Illustrated London News images seem not to have been considered worthwhile to include with the excavation records. Most likely they were the wrong kind of photograph, neither a record of the objects being carried (which were often obscured by camera angle or packing materials) nor evidence of more significant archaeological work. For Carter did incorporate 'in the field' photographs in the Tutankhamun archive,

\footnotetext{
31 Jennifer A. Baird and Lesley McFadyen, "Towards an Archaeology of Archaeological Archives," Archaeological Review from Cambridge 29 (2014): 15-33.
} 
using a sequence of Roman numbers to distinguish them from the main, Arabicnumbered series photographs that Burton took for the tomb, its artifacts, and specific occasions such as the mummy unwrapping or the opening of the burial shrines. ${ }^{32}$

Before turning to Burton's own photographs - which are the best known and most frequently reproduced - we can glean a sense of the Roman-numbered photographs from one in a series of images taken in May 1923, when crated objects from the tomb were transported by light rail more than five miles to the Nile river (Figure 6). There, they were loaded on barges to sail downstream to Cairo. This was a crucial moment: the archaeologists and antiquities officials, like Engelbach, were anxious about the condition and security of the objects along the journey, while the question of whether Cairo would be their permanent home also hung in the background. Carter and Mace (writing in Carter's voice) detailed the transport in their book on the tomb, but they did not include any of the photographs representing it. Fifty Egyptian laborers were involved in the process, which took fifteen hours over two days. The men laid and re-laid sections of light railway track as they progressed, an action Carter described as

a fine testimonial to the zeal of our workmen. I may add that the work was carried out under a scorching sun, with a shade temperature of considerably over a hundred [38C], the metal rails under these conditions being almost too hot to touch. ${ }^{33}$

[Insert Figure 6 near here.]

Reading Carter's words while viewing these images makes both the reading and the viewing more uncomfortable. In Figure 6 - negative $X V$, by his own numbering - a topee-wearing Carter strides toward the front of the train, perhaps to confer with the long-robed figure at the far right of the picture (possibly senior ra'îs Ahmed Gerigar, though it is impossible to confirm this). Alongside the crates of royal treasure are the Egyptian laborers carrying the tracks, their short shadows signaling the time of day. In the midday heat, we see where physical collaboration among the collective had its

\footnotetext{
${ }^{32}$ For a more detailed discussion of the archive, see Christina Riggs, 'Photography and archaeology in the archive, or how Howard Carter moved the road to the Valley of the Kings', History of Photography 40.3 (2016) pp 267-82

${ }^{33}$ Carter and Mace, The Tomb of Tut.ankh.Amen, Volume I, p.177 (note 4).
} 
limits, as if only the body of the 'native' was impervious to the biology of burns. ${ }^{34}$

There is a technical point to be made about 'work in progress' photographs like these, for like all the other photographs discussed so far, they were taken with handheld cameras, the popular Kodak and something similar. These easy-to-handle cameras lent themselves to on-the-spot photography and required sheet or roll film or, in some models, small-format glass negatives, no more than quarter-plate size. In Carter's archive, photographs of the sweltering light rail transport come from two different sizes of film negative, suggesting that there were two cameras in use. Burton himself had wanted to take movie footage of the transport, but his Akeley motion-picture camera had jammed while filming elsewhere a couple of weeks earlier. ${ }^{35}$ It was perhaps just as well, since tensions were already emerging between the excavators and the Egyptian authorities around issues of publicity. The Times' contract had become a bone of contention, and sensitivity to this may explain why the newspaper did not print any photographs from this series, although prints were in their possession. To document the occasion through photography was nonetheless significant, hence Burton or another team member seems to have turned to a handheld film camera instead. The use of cheaper, more portable film was in fact recommended for photographing 'everyday life' on all manner of colonial expeditions. In his work at the Giza Pyramids, Carter's rival and critic, George Reisner, kept a snapshot camera "exclusively for taking pictures of the men at work, of people and scenes encountered on our travels, and among the local inhabitants." ${ }^{36}$ For the tourist, the anthropologist, or the archaeologist, photographing 'the natives' was best done by hand and on film. There were good technical reasons for this, but there was also a regime of value at work, just as there was in the way

\footnotetext{
${ }^{34}$ For the differential construction of the 'native' body, see Simone Natale, "Photography and Communication Media in the Nineteenth Century," History of Photography 36 (2012): 451-6.

${ }^{35}$ Letter from Harry Burton (Luxor) to Albert Lythgoe (New York), 1 May 1923. Burton correspondence files, Department of Egyptian Art, Metropolitan Museum of Art.

${ }^{36}$ Peter Der Manuelian and George Andrew Reisner, "George Andrew Reisner on Archaeological Photography," Journal of the American Research Center in Egypt 29 (1992): 1-34. Anthropological expeditions likewise distinguished between different negative sizes and media, depending on the subject being photographed: Elizabeth Edwards, "Performing Science: Still Photography and the Torres Strait Expedition," in Anita Herle and Sandra Rouse (eds.) Cambridge and the Torres Strait: Centenary Essays on the 1898 Anthropological Expedition (Cambridge and New York: Cambridge University Press, 1998), pp.106-35, esp. p.116.
} 
photographs were included or excluded from the archive. It would have been a hassle, not to mention a waste of larger-format glass plates, to dignify archaeological labor with the use of a tripod-mounted view camera.

Yet Burton himself did just that. Burton, who worked for the Metropolitan Museum in Egypt for 30 years, preferred to work with large format, $18 \times 24$ centimeter glass negatives. ${ }^{37} \mathrm{His}$ are the most famous and familiar photographs of the Tutankhamun excavation, and he was credited prominently in Carter's books about the tomb as well as in The Times and The Illustrated London News. With the benefit of electric lighting in the tomb, Burton also photographed key moments leading up to the opening of the burial chamber in the second field season, an event eagerly trailed in the press. Some, but not all, of Burton's photographs of work inside the tomb were reproduced in the press and contemporary publications. Unlike other Burton negatives, which Carter divided between his own records and Burton's collection for the Metropolitan Museum, Carter kept for himself all the negatives that show men - usually including himself - working inside the tomb. Prints of the negatives appear in two (of ten) albums that Burton compiled for Carter, interspersed among other Burton photographs of the burial chamber's distinctive shrines.

Figure 7 is a Burton photograph printed in The Times on 28 December 1923, showing the demolition of the plastered stone wall separating the first chamber of the tomb from the burial chamber beyond; wooden planks (courtesy of the carpenters) protect the burial shrines on the other side. The Times' caption - "Mr Carter and Mr Callender at work" - was not unusual in ignoring the presence of the two foremen and a small boy, perched atop the ancient wooden lintel. For all the brute force the demolition required, it also needed care and close collaboration between the British and Egyptian staff. Other photographs in the sequence depict only Carter, at the start of the demolition, or only the Egyptian workers. This photograph and Figure 8, which are the last two in the sequence, bring their British and Egyptian subjects together to rather

\footnotetext{
${ }^{37}$ For Burton's work, see Erik Hornung and Marsha Hill, The Tomb of Pharaoh Seti I (Zürich and Munich: Artemis Verlag, 1991), pp.27-30; Ronald T. Ridley.
} 
awkward effect, although this did not preclude their publication. In fact, The Times would re-use Figure 8 in 1939 to illustrate Carter's obituary, cropping it to his upper body and that of the workman or ra'is next to him - Carter, the heroic archaeologist, in action. $^{38}$

[Insert Figure 7 near here.]

[Insert Figure 8 near here.]

Or was he? In both photographs, only Carter seems self-consciously aware of the camera's presence: his pose may look active, but there is no tension in his muscles, unlike the straining forearms of the Egyptian workman balancing on the wooden beam. The second Egyptian man, standing in the foreground with his back toward the camera in both photographs, is the ra'iss who supported Carter with the hippo-headed couch (Figure 2). Here, his still posture embodies a sense of expectancy, although it conveys little evident muscular tension. For that, we have to look to the balancing workman and the two British workmen who wait, backs to camera, to receive the chunks of stone the Egyptian man is working free; in Figure 7, the waiting man is Callender; in Figure 8, a man named Richard Bethell, who had joined for the second season's work. Despite the valorizing efforts of the tripod-mounted view camera and Carter's positioning of himself in front of it, these and other photographs taken by Burton to show work inside the tomb are not his most successful in technical terms. Figures - usually the Egyptian workmen - are often out of focus, or where the focus is sharp, it is all too clear that the figures (like Carter in Figures 7 and 8) are intentionally holding themselves still for the exposure. With difficult work to be done, those being photographed engaged with the photographic process in different ways, or not at all.

For a photograph in which all the actors are in sharp focus, Burton took advantage of a natural pause in the work, as Carter, Callender, and two foremen start to slide the first section of the outermost shrine forward from the shrine walls - a tense stage in the task of dismantling these unique objects (Figure 9). In the confined space of the burial

\footnotetext{
38 <ref> 'Obituary: Mr. Howard Carter', The Times 3 March 1939, p. 16
} 
chamber, grappling with fragile and heavy gilded wood, both physical and intellectual coordination were essential: it was Callender, the ex-engineer, whom Carter credited with the scaffolding, ramps, and hoists eventually needed to dismantle the shrines around the royal coffins. But it was the Egyptian carpenters who made these structures, and the Egyptian foremen who undertook the work with Callender and Carter. In the stillness that worked to the camera's advantage, we glimpse the constant communication such delicate work required, as Carter, this time, lays a hand on the ra'iss's arm, not for physical support but perhaps to offer a suggestion. The lamplight Burton has bounced off the ceiling traces the texture of the clothing both men wear and the weight of Carter's hand resting near his colleague's shoulder. For all that the gesture may speak of guidance and direction from a superior to his subordinate, it is a physical contact that speaks to close and long acquaintance, too. The Times published this photograph on 18 January 1924, captioned "Mr Carter and Mr Callender are seen with native workmen."

[Insert Figure 9 near here.]

Two months after this photograph was taken, Carter downed tools over his longrunning dispute with the antiquities service, which had had the support of the Wafd-led nationalist government over issues such as The Times' contract and who should have access to the tomb. For Carter, the final straw was the service's denial of permission for the wives of British team members to view the royal sarcophagus that had been revealed in February 1924, after all the shrines were dismantled. Carter resumed work on the tomb a year later, after the fall of the Wafd government and the election of a Liberal Constitutionalist government more acquiescent to British interests. From that point, the antiquities services, rather than Carter, issued bulletins to the press, and although Carter maintained a close relationship with The Times, including use of Burton's photographs, all press coverage was less intense than during the first two 
seasons. ${ }^{39}$ Apart from occasional group shots, for instance on the occasion of the mummy unwrapping in November 1925, and a few carefully staged images of Carter with the royal coffins the same season, Burton no longer took work-in-progress photographs.

Instead, Burton focused on what had always been the core of his work: in situ photographs at stages of clearance inside the tomb, and object photography after the artifacts had been restored and recorded on index cards. One photograph from the latter years of Burton's work on site offers a fitting image to round off this discussion of archaeology as a collective effort, for it reminds us that photography too was a collaborative endeavor in the work of archaeology (Figure 10). For prints, which he filed in albums for Carter and the Metropolitan Museum dig house, Burton cropped the negative to the bed, removing the number card, the stone walls, the edges of the backdrop, and the blurred, just-glimpsed figures of the assistants he referred to as his "camera boys," regardless of their age. ${ }^{40}$ Burton is always the only person credited as the photographer, but he did not work alone. Photographs of Burton at work in Egypt often show three or four Egyptian men nearby, whose responsibilities will have included help with set-up, backdrops, and reflectors, but may also have encompassed darkroom tasks, equipment maintenance, and supervision of supplies. Only one is ever named, not by Burton but by his widow Minnie, in a letter she wrote from Cairo to his former employer, Ambrose Lansing, at the Metropolitan Museum in the months after Burton's death. It is a revealing letter for what it says about life, and labor, in the contact zone:

The only other person I have heard from of the Luxor staff (except their joint letters of sympathy) was Harry's Hussein who wrote + asked me to try + help him to find work. But I didn't know what he was fit for - having, as far as I knew, done nothing but camera work for 20 years or so. He came here to see me the other day + said he was on his way to Suez as he had heard there was work to be found there. Poor fellow - he wept when he spoke of Harry. He told me not to cry. He said "Mr Burton is dead. I too will be dead

\footnotetext{
${ }^{39}$ Donald M. Reid, "Remembering and Forgetting Tutankhamun: Imperial and National Rhythms of Archaeology, 1922-1972," in William Carruthers (ed.) Histories of Egyptology: Interdisciplinary Measures (New York and London: Routledge, 2015), pp.157-73.

${ }^{40}$ Harry Burton, "The Archaeologist as Photographer," The New York Times, 15 February 1923; reproduced in Polly Cone (ed.), Wonderful Things: The Discovery of Tutankhamun's Tomb (New York: Metropolitan Museum of Art, 1976), pp.11-17.
} 
soon, + so will you + everyone else. Mr Burton was a good man + he is with god, + you will find him there. He knows where you are + what you are doing." Don't you think that was extraordinary? It was just about Kurban Bayrami [the Eid el-Adha], so I gave him a pound (Harry always did) + my blessing. He told me the others were all well, except $\mathrm{Mr}$ Winlock's Salama (I don't remember him) who had died suddenly recently, but I didn't understand what he died of. ${ }^{41}$

[Insert Figure 10 near here.]

Like other wives of the Museum's Egyptian Expedition staff, Minnie Burton had accompanied her husband in Egypt for thirty years, living in the dig house and encountering - albeit in more restricted contexts - many of the same Egyptian workmen. A relationship of exchange and responsibility clearly existed between Burton and Hussein, which Minnie as Burton's widow felt obliged to continue, despite her evident confusion over Egyptian staff whom Hussein assumes she will remember, and over Hussein's own fitness for any form of employment other than an archaeological dig. Her letter reports a conversation at the heart of the contact zone, where the asymmetries, inequalities, and differences inherent to collective effort can be seen behind the camera, as well as in front of it.

\section{Conclusion}

Although the tomb of Tutankhamun may have been near-unique for the public interest its excavation generated, the centrality of photography in the work of the excavation was not. Through photographs of work at the tomb, their publication in the press, and their various archival trajectories, we can disassemble the narrative of the herodiscoverer and scientific objectivity and reassemble in its place a counternarrative that restores texture, nuance, and complexity to the collective effort of archaeology in the colonial and semicolonial context of interwar Egypt. Egyptians in their hundreds, and from across the social spectrum, played fundamental roles in the most famous archaeological discovery ever made in Egypt. They shouldered their past both literally and figuratively, from rough laborers to experienced foremen, and from cooks, cleaners, guards, and soldiers to the tarbush-wearing effendiyya of the new nation-state's

\footnotetext{
${ }^{41}$ Letter from Minnie Burton (Cairo) to Ambrose Lansing (New York), 16 January 1941; Burton correspondence files, Department of Egyptian Art, Metropolitan Museum of Art.
} 
officialdom, whose Ministry of Public Works (administrative home of the antiquities service) oversaw it all. Newspaper and excavation archives - in both of which photographs feature prominently - show this collective effort quite clearly, for all that it has been underrepresented, if not invisible, in the multitude of books, exhibitions, and media Tutankhamun continues to generate. ${ }^{42}$

Why photograph the working processes of archaeology? In this paper, several answers to this question have emerged through photographs of work in progress at the tomb of Tutankhamun. Photographs contributed to discursive strategies that positioned archaeology as a scientific practice defined by rigor, accountability, methodology, and objective facts. As such, archaeology was also the reserve of white, male protagonists, depicted (ideally) in photographs in roles of active and accomplished command. But the abundance of information that photography records, as well as the numerical abundance of photographs that a famous find like Tutankhamun encouraged, permits a refiguring of photographic evidence and affect to foreground the collective nature of archaeological labor and knowledge production. Importantly, photography was itself one of the working processes of archaeology, regardless of whether 'work' was explicitly the subject in front of the camera lens. Colonial-era archaeology helped create, reify, and reinforce inequalities and injustices that cast long shadows, for all that the discipline's positivist aims and media-friendly pharaohs may seem unperturbed. The click of the Kodak and the shunt of the dark-slide have left us with photographic archives rich with potential to reenter the contact zone and retrieve something of the embodied and emotional experiences it shaped, in all their confusion, discomfort, or

\footnotetext{
${ }^{42}$ For Egypt, the government's own archives, the Arabic-language press, and any personal archives kept by Egyptian officials or site workers are another potential, and potentially rich, source of information, but language and access barriers have placed these beyond my own investigative scope here. Like other nonArabic speakers, I am indebted to the scholarship that does draw on Arabic-language sources, such as Colla, Conflicted Antiquities (note 4); Wendy Doyon, "On Archaeological Labour in Modern Egypt," in William Carruthers (ed.) Histories of Egyptology: Interdisciplinary Measures (New York and London: Routledge, 2015), pp.141-56; Reid, "Remembering and Forgetting Tutankhamun" (note 41). On photographic archives in contemporary Egypt, see Lucie Ryzova, "Mourning the Archive: Middle Eastern Photographic Heritage between Neo-liberalism and Digital Reproduction", Comparative Studies in Society and History 56.4 (2014) pp. 1027-61
} 
tedious banality. Photographers like Burton valued shades of gray. So, sometimes, should we.

Funding

This work has been funded by the following grants:

British Academy Mid-Career Fellowship MD140004, Leverhulme Research Fellowship RF-2015365 